\title{
Production-Based Curriculum Development in Vocational High Schools for Preparing Skilled Labor in Industry
}

\author{
Yoto \\ Mechanical Engineering Education Department \\ Universitas Negeri Malang \\ Malang, Indonesia \\ yoto.ft@um.ac.id
}

\begin{abstract}
The development of Vocational High Schools (VHS) aims to create a qualified, sophisticated, independent, and modern Indonesian society that contributes significantly to the achievement of overall national development goals and to improve the nation's dignity. VHS development covers a wide range of dimensions, including social, cultural, economic, and political dimensions. Vocational education is a provision to deal with and solve the problem of life, both as an independent individual, community, and citizen. To achieve the success of VHS development comprehensively, the curriculum development should be done continuously, referring to the needs and development of the industry called "Production Based Curriculum." If this can be achieved, the limitations on skilled labor availability can be gradually solved meaning that national productivity will increase and the welfare of society also gradually increase.
\end{abstract}

Keywords—skilled labor, industry, production-based curriculum

\section{INTRODUCTION}

One of the objectives of Indonesian Government is to educate the life of the nation. Therefore, every Indonesian citizen is entitled to obtain qualified education in accordance with his interests and talents without looking at social, racial, ethnic, religious, and gender status as mandated in the preamble of the 1945 Constitution. Equity and quality of education will make Indonesian citizens have life skills to help them recognize and overcome their problems and environment. In addition, life skills also help them to encourage the establishment of civil society and modern that is imbued with the values of Pancasila. The ministry of National Education, the holder of the mandate of the implementation of the national education system, must realize the development mission. What kind of man would you like to build? The perspective of educational development is not only aimed at developing the intellectual aspect but also the character, morale, social, and physical of learners, or in other words creating the whole Indonesian people [1].

Vocational education is a combination of theory and practice which are balanced with the orientation on the job readiness of graduates [2]. The curriculum in vocational education is concentrated in the apprenticeship of learning system on specific trades. The advantages of this vocational education, among others learners, can directly develop their skills tailored to the needs of the field or field of tasks that will be faced $[3,4]$.
Vocational education is a central issue in education services today. It is a bridge between the preparation of students in educational institutions with the community and the world of work [5]. Vocational training specifically becomes the content of the curriculum in the form of functional skills and professional personality lessons. In addition, vocational training through science and technology subjects with the thematic, inductive, and people-oriented approach in their region is also applied.

Many opinions and literature suggesting the notion of life skills is not just a skill to work (vocational) but has a broader meaning. The World Health Organization (WHO) defines life skills as skills or abilities to adapt and behave positively, enabling individual to face more demands and challenges in life more effectively [5]. Life skills include five types, namely: (1) self-knowing skill, (2) thinking skill, (3) social skill, (4) academic skill, and (5) vocational skill.

Life skills are self-development to survive, grow, and develop, have the ability to communicate and connect individually, in groups and through systems in the face of certain situations [1]. While the United Nations Educational, Scientific and Cultural Organization says that life skills are interactions of diverse knowledge and skills so that one can live independently [6]. The definition of Life Skills is not solely a vocational job, but it also has the functional support of functional skills such as reading, writing, arithmetic, formulating and solving problems, managing resources, working in groups, and using technology.

From the above explanation, it can be formulated that vocational education is a skill that can practically equip learners in overcoming various problems of life. The skills are related to aspects of knowledge, physical and mental attitudes, and vocational skills related to the moral development of learners to be able to face the demands and challenges of life in the community, nation, and state.

\section{METHOD}

The dual system education and training developed by the Government of Germany was much exemplified by countries in Europe. While the first model of education and training in the United States was to create competency-based education and training, to improve Competency-Based Education/Training (CBET), it also noticed the development of dual systems [3]. Competence-based education and training also received attention from developing countries in 
Asia. In the 1980s some of the countries focused their efforts on industrialization and entered the world market. This has led them to direct the vocational education system to CLCC which is based on studies proven to increase participation to support the success of industrialization and the economy.

Vocational High School Development in Indonesia is an effort aiming to realize a qualified, advanced, independent, and modern society. The development of vocational education is an essential part of the overall and serious efforts to improve the dignity of the nation [5]. Success in building education will contribute significantly to the achievement of overall national development goals.

In this context, the development of vocational education covers a vast range of dimensions, including social, cultural, economic, and political dimensions [5, 7]. In a social perspective, vocational education will produce educated people who have an essential role in the process of social change in society.

In a cultural perspective, education is an important vehicle and an effective medium for teaching norms, socializing values, and instilling ethos among citizens. Education can also be an instrument to nurture the nation's personality, strengthen and establish national identity.

In an economic perspective, vocational education will produce reliable humans to be the subject of driving national economic development. Therefore, education should be able to give birth to qualified graduates who have the knowledge, master technology, and have adequate technical skills and life skills. According to Zazin, from an economic perspective, high quality education should be able to improve the welfare of human life to contribute to the economic growth of society. Education should also be able to produce professionals who have entrepreneurial skills which became one of the main pillars of national economic activity [7]. Even the role of education becomes very important and strategic to enhance national competitiveness and build the independence of the nation, which becomes the absolute prerequisite in entering the competition among countries in the global era.

In today's global era, various nations of the world have developed knowledge-based economy (KBE), which requires qualified human support $[3,5]$. Therefore, education is necessary to sustain the development of the knowledge-based economy. In this context, educational institutions should also serve as the center of research and development, resulting in superior research products that support the KBE. The availability of qualified human beings dominating science and technology dramatically determines the nation's ability to enter global competence and free market economy, which demands high competitiveness. Thus, vocational education is expected to enable Indonesia to achieve excellence in global competition.

In a political perspective, vocational education must be able to develop the capacity of individuals to become good citizens with the awareness of rights and responsibilities in the life of society, nation and state, [5]. Therefore, education should be able to give birth to individuals who have the vision and idealism to build a collective strength as a nation.

Vocational education management program through standardization, quality assurance, and accreditation of units or educational programs that have been done so far will be more focused on the institutional arrangement and quality of graduates [7]. All this is done without discrimination to the previous programs related to the ease of access to education and public accountability in its implementation.

\section{RESUlT AND DisCUSSION}

The curriculum of 2013 in vocational high schools promises the birth of the productive, creative, and innovative next generation with character. With creativity, the nation's children can innovate productively to meet the increasing complex challenges of the future. Nevertheless, the 2013 curriculum is expected to produce productive, creative, and innovative people [8].

In an educational system, the curriculum is dynamic; always change and develop to keep up with the developments and challenges of the time. However, the change and development of vocational curricula should be systematic efficient, effective, continuous, objective, democratic and directed to the principles of goal-oriented, as well as relevant to industry needs [9].

The vocational education curriculum is developed by taking into account: (1) The formation of the students' personalities as a whole, whether in faith, devotion, and noble character; (2) Allowing the development of the diversity of values, interests, and talents, intellectual, emotional, spiritual, and kinesthetic learners optimally by the level of development; (3) The curriculum must fit the demands of the world of work and the necessities of life; (4) Vocational programs should enable students to enter the world of work; (5) The skills that need to be developed include personal, social, academic, and vocational skills; and (6) The development of science, technology, and art [5].

Vocational High schools are educational and training processes that provide students with knowledge and skills to compete in the face of competition in the workplace (Finch and Crunkilton, 1989; Singh and Sudarshan, [10,11]). The learning process in vocational education should be equipped with sufficient practical equipment/facilities to have a functional training activity according to the conditions in the industry [12]. Training activities in vocational schools should reflect productive work activities as practiced in the industry. So the implementation of school activities should be able to provide work experience and simulate activities following what is needed in the workplace [13,14].

To fulfill it, the readiness of the human resources quality of Indonesian workforce should be further enhanced. Therefore, it needs to be prepared through a customized vocational education system to be able to address the needs of ready-to-work human resources [15]. To face these challenges, the curriculum must be able to equip learners with various competencies required by the industry. This means that the primary focus of the vocational education development curriculum program is to develop a productionbased curriculum as required by the industry as a labor output user of vocational education.

To fulfill the production-based curriculum as required by the industry, the characteristics of vocational education curriculum are: (1) the success of vocational education is not solely measured by the students' success in the learning process, but through the success of work, ie in the form of graduate performance in the world of work; (2) the development of vocational education curriculum is prepared 
based on the opportunity of students to get a job after graduation; (3) the vocational education curriculum should also have the potential to help students develop knowledge in a broad range of skills, attitudes, and values that make it easier to get a job; (4) the assessment of the students' success in the vocational school must be aligned with the applicable performance required in the world of work; (5) the success of graduates in the world of work can be used as an indicator of the alignment of educational curriculum in vocational schools; (6) the cooperation between schools and with industry can assist the need for practical activities relevant to the curriculum; (7) the availability of productive teachers who are competent in their field, quickly follow the development of science and technology, creative, and innovative; and (8) the availability of sufficient funds, given the funding of vocational schools is very expensive and vulnerable to change $[3,10,12]$.

To implement the curriculum, the quality of vocational education program requires several solid foundations: (1) professional and strong leaders for commitment and change, (2) clear understanding of existing conditions, (3) have a clear vision of the future, and (4) a clear and realizable program [16]. The subjects in vocational education consist of theory, practicum, workshop, fieldwork, and the final project [4]. Basically, the curriculum at vocational high school (VHS) is the same as that of the vocational higher education, which emphasizes the mastery of skills competence. Therefore, to achieve the curriculum goals, it requires commitment and strong leadership as well as professionalism.

The most critical subjects in the development of vocational education curriculum are practical subjects, consisting of (1) improved understanding, insight, and vocational skills implemented in laboratories, workshops, and studios; (2) industrial skill enhancement and industry insights are applied in industries in accordance with their areas of expertise through Field Work Practice [17]. One of the efforts to provide mastery of the material in the field of vocational engineering studies is the holding of learning processes in the laboratory/workshop [18]. The purpose and function of the laboratory in vocational education are to support the learning process closely related to understanding, skills, verification, and innovation in science as well as working in the field of study [18].

Based on the description described above, the production-based learning process in vocational high schools is categorized into input, process, and output. Input consists of students, facilities, funds, teachers, and production-based curriculum; the learning process is carried out in schools and industries in the form of basic theory and practice undertaken at school. Field Work Practice is conducted in industry, and evaluation activities comprise of Semesters Final Exam, Grade promotion Exam, Schools Final Exam, National Exam, and certification; while its output is a graduate ready to compete in the world of work (see Figure 1).

In the future, the required curriculum by the global development includes the curriculum containing these competences: communication skills, the ability to think clearly and critically, the ability to consider the moral aspect of a problem, the ability to be responsible citizens, the ability to try to understand and tolerate different views, the ability to live in a globalized society, having a fixed interest in life, having the readiness to work, having intelligence according to their talents/interests, and having a sense of responsibility towards the environment [8].

The success of the production-based curriculum, besides the existence of several characteristics that must be met as described above, it must be supported by the implementation of sufficient laboratory practices/workshops in school. It means that practicum activities in vocational schools should reflect work activities in the industry. The accuracy of the work, discipline, responsibility, the use of safety and health equipment should be familiarized with the students during practical work in the laboratory / workshop at school. If this is done, then the formation of character and work culture will be realized. So that after finishing the education from vocational schools, learners will have the ability, skills, and competitiveness in the world of work.

The steps of developing a production-based curriculum in vocational high schools are: (1) preparing facilities and infrastructure practices that comply in school; (2) providing teacher resources with experience and skill in order to teach practice subjects, therefore teachers should have industry experience; (3) establishing a harmonious relationship between school and industry as a partner institution; (4) synchronizing curriculum, which is a production-based curriculum compiled together by schools and industries used for learning, whether the learning is done at school or in the industry when the students do industrial work practices, and (5) implementing learning in schools through practical activities, practice activities are not just simulations but students are also asked to do the work as it is in the industry through Teaching factory activities in school; and (6) students undertake production-based learning in the industry through industrial work practices.

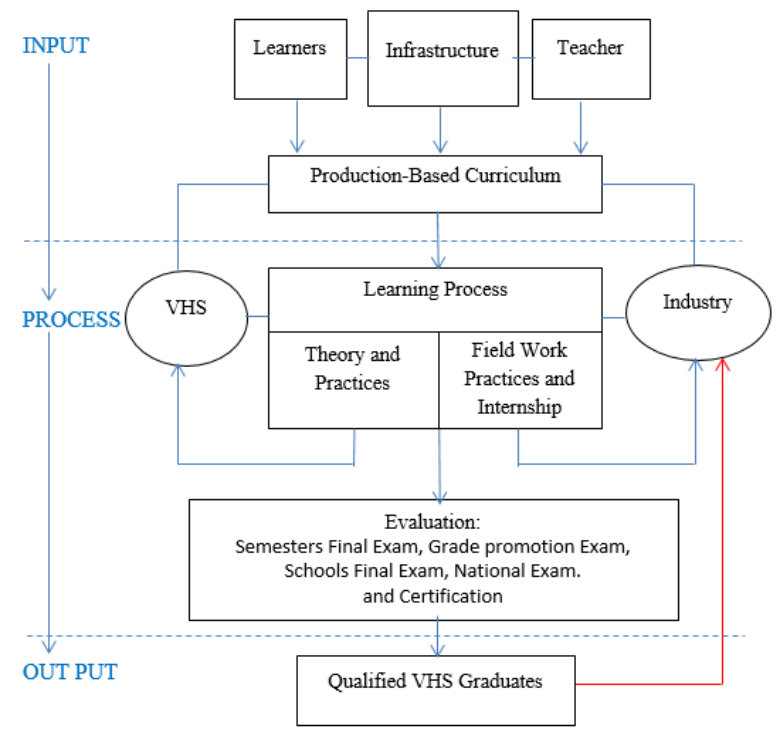

Fig. 1. Educational Process of Vocational High School

\section{CONCLUSION}

The development of vocational high schools aims to create qualified, advanced, independent and modern Indonesian society, and contribute significantly to the achievement of overall national development objectives, as well as to improve the nation's dignity. 
To realize the successful development of vocational high schools comprehensively, curriculum development should be sustainable and refers to the needs and development of the industry with a focus on "Production-Based Curriculum."

\section{REFERENCES}

[1] Depdiknas, Education sector review, Jakarta: Balitbang, Departemen Pendidikan Nasional, 2002.

[2] Depdiknas, Reposisi pendidikan kejuruan menjelang 2020, Jakarta: Depdiknas Dirjen Dikdasmen Direktorat Dikmenjur, 2011.

[3] Reksoatmodjo, Tedjo Narsoyo. Pengembangan kuriukulum pendidikan teknologi dan kejuruan. Bandung: Refika Aditama, 2010.

[4] Kemenristekdikti, Panduan penyusunan kurikulum pendidikan vokasi. Jakarta: Kemenristekdikti Dirjen Pembelajaran dan Kemahasiswaan, Direktorat Pembelajaran, 2016.

[5] A.N. Sumarto, Pendidikan berkelanjutan dalam bidang vokasi. aptekindo conference proceedings, Bali: universitas pendidikan ganesha, 2010.

[6] UNESCO, The dakkar for action; education for me; meeting our collective commitment. France: Unesco, 2005.

[7] N. Zazin, Gerakan menata mutu pendidikan teori dan aplikasi. Yogyakarta: Ar-Ruzz Media, 2011.

[8] Mulyasa, Pengembangan dan implementasi kurikulum 2013, (Remaja Rosdakarya, Bandung, 2014)

[9] Sudirman, Ilmu pendidikan (Kurikulum, program Pengajaran, CBSA, Metode dan Media Pendidikan), Bandung: Remadja Karya, 1989).
[10] C.R. Finch, and J.R., Crunkilton, Curriculum development in vocational and technical education $\left(3^{\text {rd }}\right)$ ed., Massachusetts: Allyn and Bacon, Needman Heights, Inc, 1989.

[11] U.K Singh, and K.H. Sudarshan, Vocational education. New Delhi: Discovery Publishing House PVT.LTD., , 2015.

[12] S. Billett, vocational education: purposes, traditions, and prospects, Queensland: Griffith University, 2011).

[13] M.D.Miller, Principles and a philosophy for vocational education, Columbus: Ohio State University, 1985).

[14] OECD, Learning For Jobs, Synthesis Report of the Organisation For Economic C0-Operation And Development (OECD) Reviews of Vocational Education and Training, 2010.

[15] R. Ramelan, B. Iskandar, and S. Handayani, Report of Hibah Kompetitif Program Unggulan UPI, Jakarta: Pusat Kajian SMK, 2009.

[16] N.S. Sukmadinata, A.N. Jami'at, and Ahman, Pengendalian Mutu Pendidikan Sekolah Menengah (Konsep, prinsip, dan instrumen), Bandung: Refika Aditama, 2008.

[17] Ridawati, Implementasi Sertifikasi Iso Untuk Laboratorium Di Lembaga Pendidikan Tinggi Kejuruan. Makalah disampaikan dalam Forum Seminar Internasional dengan Tema Peran LPTK Dalam Pengembangan Pendidikan Vokasi di Indonesia, 2010 [APTEKINDO Conference Proceedings Universitas Pendidikan Ganesha, Bali, 2010].

[18] Yoto, Manajemen Bengkel Teknik Mesin. Malang: Aditya Media Publishing, 